\title{
PSYCHE.
}

\section{SOME OLD CORRESPONDENCE BETWEEN HARRIS, SAY, AND PICKERING.-VI.}

[PICKERING TO SAY.]

Salem, Sept. $9^{\text {th }}$, 825 .

Dear Sir,

I take the present opportunity to forward you a few specimens of insects. The brown butterfly inhabits the bald summits of the White mountains of New Hampshire and appeared to be confined to those regions. Mr. Nuttall described to me a year ago an insect from the same locality probably identical with this, but unfortunately his specimens were lost. The white Pieris occurred not unfrequently about the base of the mountains, together, with a fine species of Apatura? with a broad white band across the middle of each wing, of which I was unable to procure more than a single specimen. The small Lycæna was taken in a bog meadow in this vicinity. Your Cicindela formosa I have frequently met with in this vicinity, and particularly, it occurred in great numbers, for two successive years, at a sandy spot near Cambridge in this state: the other $\mathrm{Ci}$ cindela, of which I have sent you the two extremes in the variation of the markings, is distinguishable at first sight from C. sexguttata by the convexity of the elytra and also by the comparative dullness of the colors when alive, occurred abundantly at the same locality and I have met with it no where else. The Pollyxenus I met with two or three times this last spring under the bark of the Walnut; on the side of the White mountains under the bark of a dead pine I took a single specimen of the genus Craspedosoma which I have by me now though it is very much injured. The black Leptura is also from the sides of the White mountains. The Tipula is found in ditches in bog meadows in this vicinity and makes a curious appearance when flying, the six legs are then extended and become very conspicuous, slowly moving along, while the means by which the motion is produced are not seen. I have filled up the box with duplicates from my collection (which unfortunately are rather scarce particularly of the more uncommon species) of the genera Leucopsis, Plea Leach, Xylota?, Syrphus, Nemotelus, Stomoxys, Hydrometra, Curculio, Luperus, Clytus, Cychrus, \&c ; if among these you find anything interesting I shall be able to give you further information.

Yours, with respect, Charles Pickering. 
[DRAFT OF REPLY BY THOMAS SAY.]

$$
\text { October I } 2 \text { th, I825. }
$$

I thank you much for the specimens of ins. you were so good as to send me, as well as for the agreeable letter which accompanied them; in the care of $\mathrm{Mr}$. Robinson they all arrived in excellent order.

The Pollyxenus you met w. is ["perhaps" erased] the P. fasciculatus Nob. if so the species has a wide range.

Pieris, I have not met $\mathrm{w}$. this $\mathrm{sp}$. before \& do not know it, have you both sexes?

Limenitis arthemis, Drury, the Butterfly w. a broad white band across ea. wing.

Lycaena phlœas, var.

Cicindela formosa. I am surprised to learn that this is $f^{\prime} d$ in y'r region; I've never met $w$. it here. I think you will find the green Cicindela to be a variety of C. 6-guttata, I have some specimens on which the punctures are very large so as to give the surface a very rough appearance.

The Craspedosoma must be interesting, I have not yet found a sp'n in this country.

The black Leptura is my $L$. pubera. "The Tipula found in ditches \&c" is Ptychoptera clavipes of authors.

The brown butterfly is my Hipparchia semidea. I received a mutillated specimen from Mr. Nuttall, but yours is in good order. I propose to figure it: in $\mathrm{my} 3^{\mathrm{rd}}$ or $4^{\text {th }}$ vol. (the marbling of the under sides of hind wing is much as in $\mathrm{H}$. semele, but the dark lines are broader.)

The Leucospis is a small sp'n of my L. affinis.

The Prince of Musignano will deliver you this letter if he goes so far as Salem, if not he will put it in the Boston post office.

Melandrya labiata Nob.

\section{DESCRIPTIONS OF OESTRID LARVAE TAKEN FROM THE JACK RABBIT AND COTTON-TAIL. \\ BY C. H. TYLER TOWNSEND, LAS CRUCES, N. MEX.}

Our jack-rabbits and cotton-tails are frequently badly infested with bots, but the former are usually the worse infested. The jack-rabbit of this region is the Lepus callotis of Wagler; while, if I am not mistaken, our cotton-tail is the sage hare, Lepus artemisia of Bachman (or possibly L. bachmani Waterh.) Jack-rabbits are sometimes seen with immense, unshapely lumps on their shoulders, sides or backs. Whether or not these are due to bots, I can not say positively, as I never succeeded in securing a rabbit in this condition. I have been told that when these lumps are cut open, they reveal simply a collection of sacs filled with a watery substance, but without bots.

It may seem strange to record that the jack-rabbit bot is a Dermatobia, while the bot of the cotton-tail is, as a rule a Cuterebra. Such, however, is the case. While I have not observed any instance as yet of the Cuterebra in- 

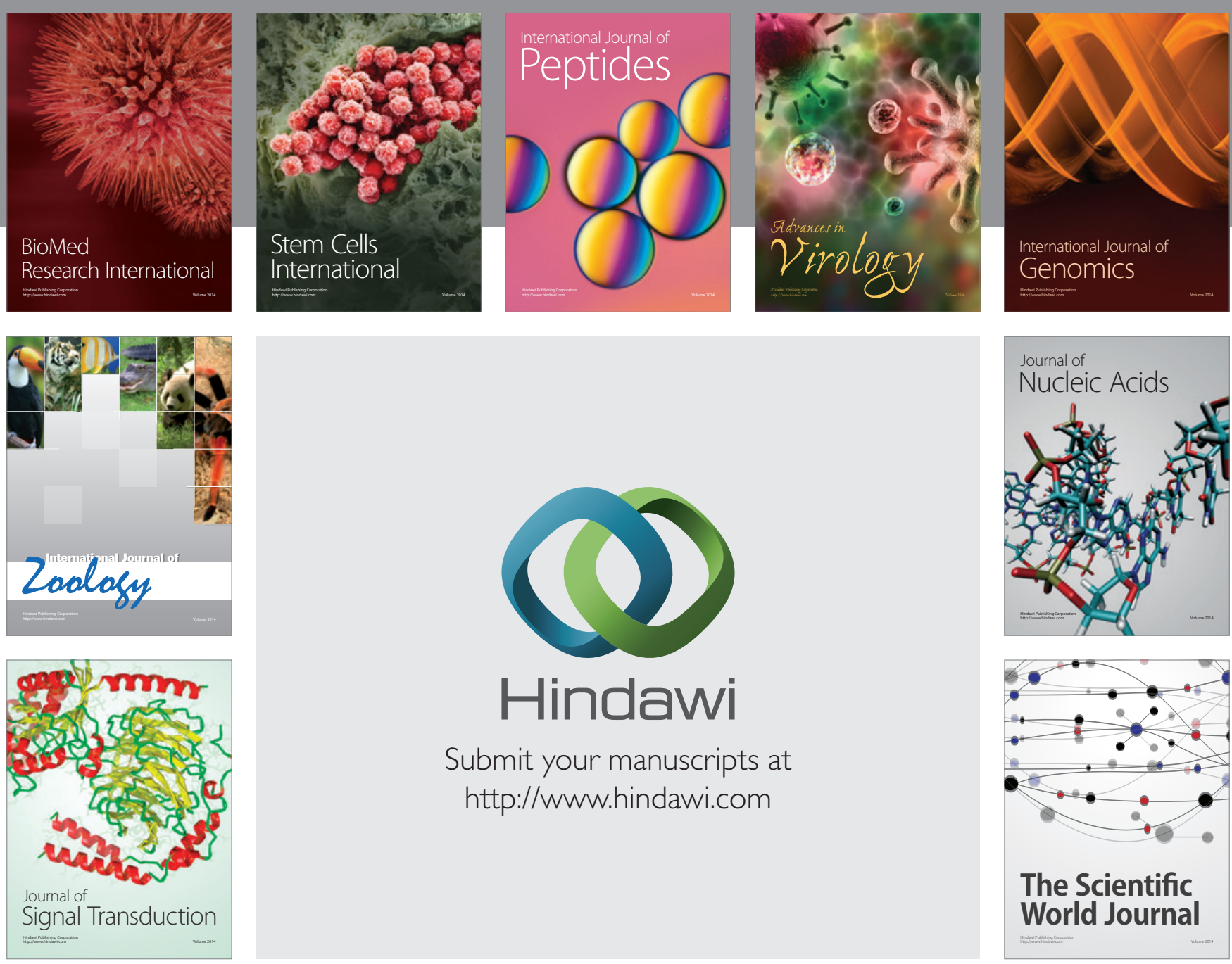

Submit your manuscripts at

http://www.hindawi.com
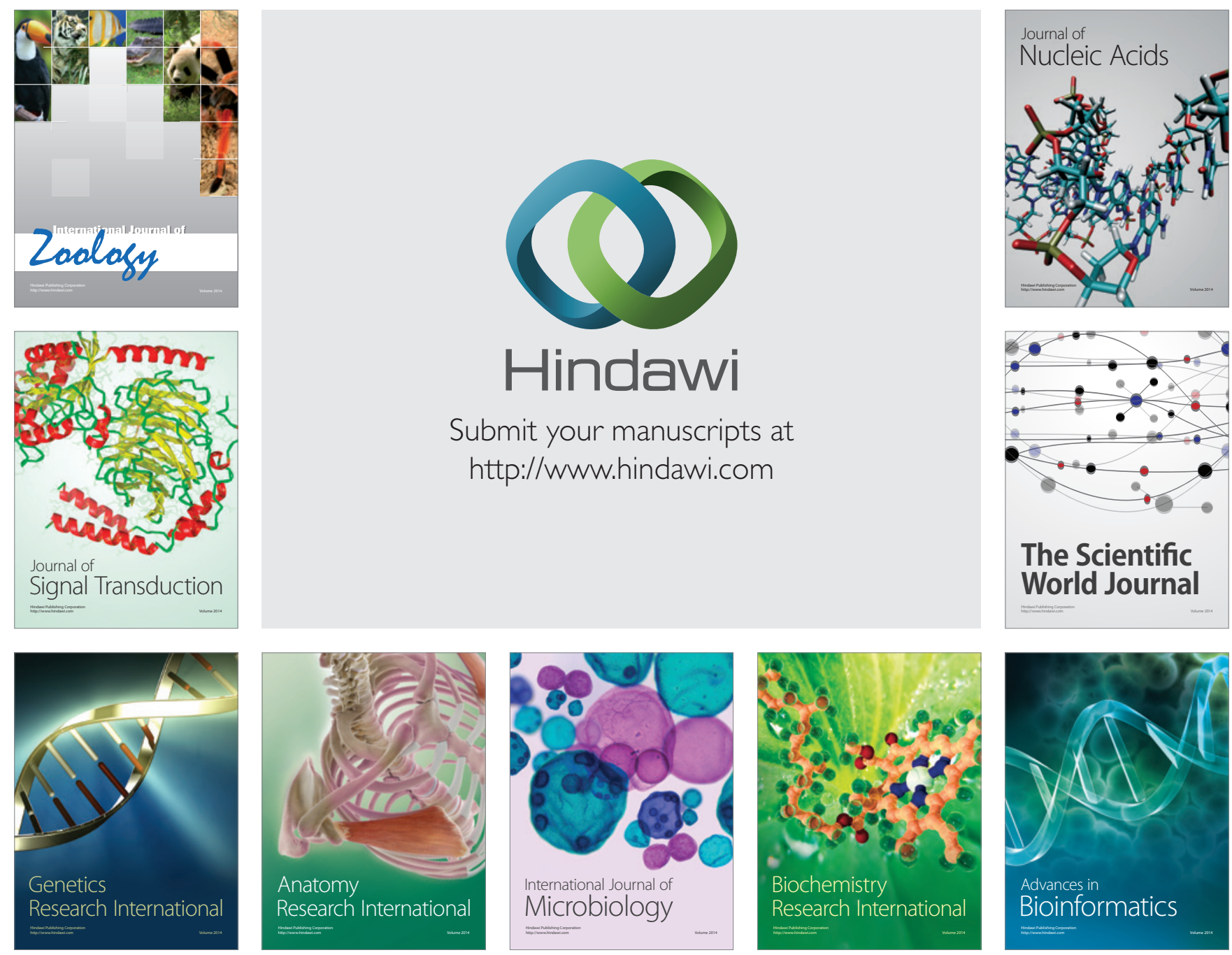

The Scientific World Journal
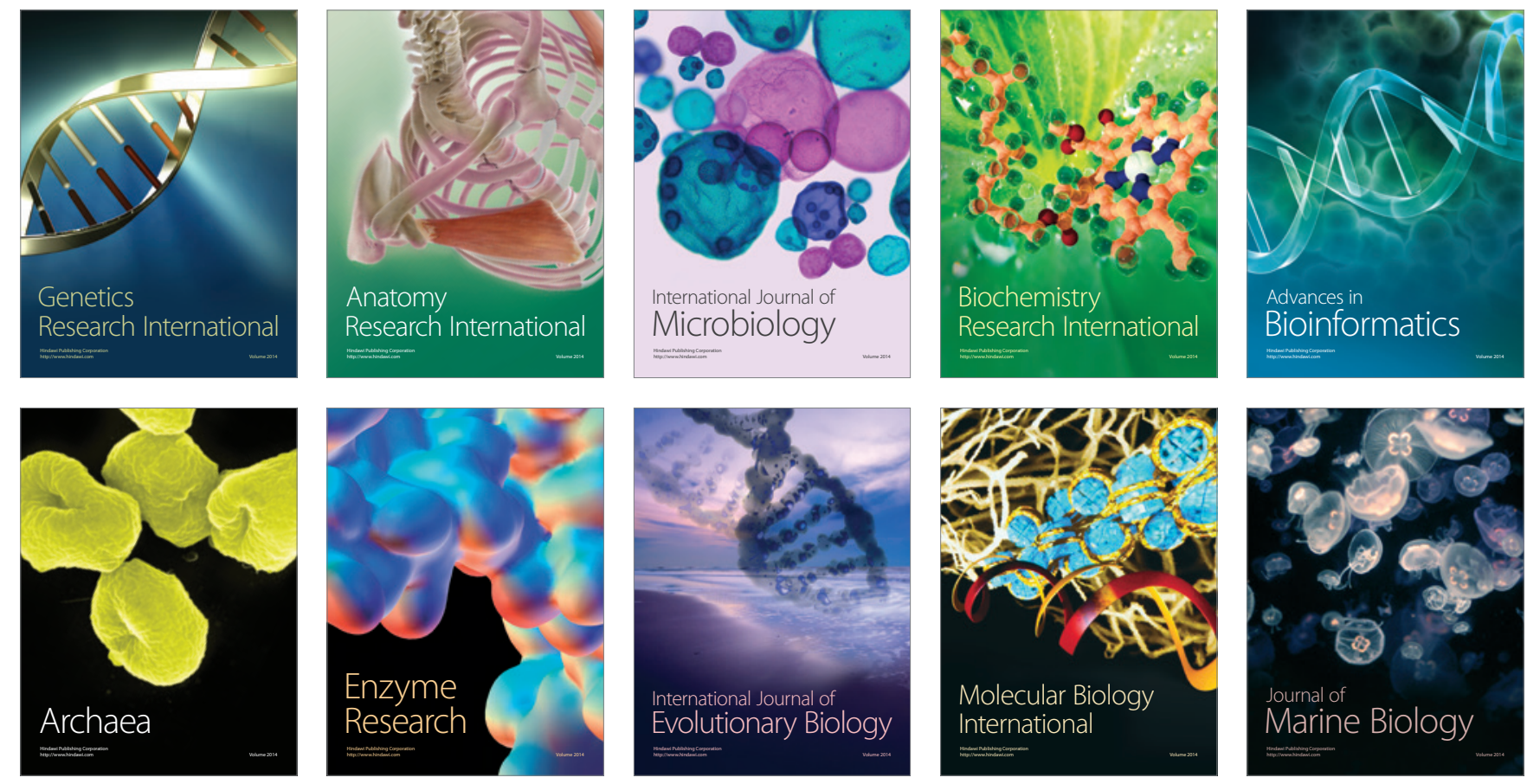